\title{
STUDIES ON THE ABSORPTION OF CAROTENE IN MAN
}

\author{
TSUYUKO KAWAGUCHI AND AKIJI FUJITA
}

Biochemical Laboratory, Kitasato Institute, Minato-ku, Tokyo

(Received March 10, 1956)

The chief source of vitamin A of the Japanese is carotene, especially $\beta$ carotene. It is therefore important to know the absorbability of carotene in order to determine the vitamin requirement of the Japanese but studies concerning the matter have scarcely been performed in Japan. A survey of the literature shows that this problem has not been fully established in other countries and the results of various investigators are scarcely in accord. According to the view of the authors, it seems to be highly questionable whether carotene, especially $\beta$-carotene in feces, has been accurately measured. The authors have conducted a detailed study of carotene absorption in Japanese using an assay method which had been established by the authors for determining $\beta$-carotene in feces.

\section{EXPERIMENTAL}

\section{Subject.}

\section{Methods}

The experimental subject was a 46-year-old, healthy female, weighing 46 $\mathrm{kg}$ and $152 \mathrm{~cm}$ in height. Exercise was limited to light house work and heavy manual labor not permitted.

\section{Method of $\beta$-Carotene Determination}

The total quantity of feces for 24 hours was measured, mixed well, a suitable aliquot (about $3 \mathrm{~g}$ ) was taken, ground well, extracted with $3 \mathrm{ml}$ methanol and filtered through a sintered-glass filter. The residue was extracted several more times with methanol to make a total volume of about $10 \mathrm{ml}$. The same process was repeated with benzene until the filterate became clear (usually $20-30 \mathrm{ml}$ ). The benzene layer was evaporated off leaving a volume of about $10 \mathrm{ml}$. To this was added $10 \mathrm{ml}$ of 5 per cent $\mathrm{KOH}$-ethanol and mixed well. After standing for about 10 minutes, $10 \mathrm{ml}$ of water was added, the solution shaken well and the benzene layer collected. This was washed two times with an equal volume of 60 per cent methanol and then twice with $20 \mathrm{ml}$ water. The benzene layer which had now become clear was evaporated off, the residue was dissolved in $3 \mathrm{ml}$ petroleum ether and $1 \mathrm{ml}$ of the solution was used for chromatography. For this purpose calcium hydroxide columns, $0.7 \times 15 \mathrm{~cm}$, were used. One $\mathrm{ml}$ of the carrotene solution was placed on the column and developed with petroleum ether only. Approxi- 
mately $20 \mathrm{ml}$ was required. First, $\alpha$-carotene flowed down and after an interval, $\beta$-carotene followed. The $\beta$-carotene fraction was taken in a test tube, diluted with a suitable quantity of petroleum ether and the optical density was measured with the Beckman spectrophotometer $(450 \mathrm{~m} \mu, 1 \mathrm{~cm})$. The conversion factor for calculating the $\beta$-carotene concentration, f, i.e., $(\gamma / \mathrm{ml}) / E$ was taken as 3.84. Under these conditions, the added $\beta$-carotene was practically completely recovered. No special treatment for saponification was found necessary.

\section{Basal Diet.}

The basal diet was made up as similar as possible to the normal daily diet of the subject. The daily intake was 2000 Calories with $70 \mathrm{~g}$ protein and almost no carotene was contained. Though there were some variations according to the season and course of the study, the diet was approximately that shown in Table I.

\section{Experimental Diet.}

Food containing carotene to be tested was administered at one meal, lunch. Test samples containing margarine or oil were incorporated in mashed potato and given. Strained pumpkin was sweetened with sugar and given in place of Irish potato. When margarine was added to this, the margarine was mixed in during the process of straining. Care was taken to use margarine which did not contain carotene.

TABLE I

Composition of the Basal Diet.

\begin{tabular}{|c|c|c|c|c|c|}
\hline Time & Menu & Ingredients & Weight & Cal. & Protein \\
\hline Breakfast & $\begin{array}{l}\text { Bread } \\
\text { Fruit } \\
\text { Tea }\end{array}$ & $\begin{array}{l}\text { Bread } \\
\text { Margarine } \\
\text { Apple } \\
\text { Black tea } \\
\text { Sugar }\end{array}$ & $\begin{array}{c}g \\
150 \\
10 \\
100 \\
\text { Small } \\
10\end{array}$ & $\begin{array}{r}376 \\
74 \\
46 \\
40\end{array}$ & $\begin{array}{r}g \\
10.5 \\
-\overline{0} \\
-3 \\
-\end{array}$ \\
\hline Lunch & $\begin{array}{l}\text { Pickled squid } \\
\text { (1) Cooked vegetable } \\
\text { (2) Mashed potato } \\
\text { Pickle } \\
\text { Rice }\end{array}$ & $\begin{array}{l}\text { Squid } \\
\text { Irish potato } \\
\text { Dried onion } \\
\text { Sugar } \\
\text { Soy bean sauce } \\
\text { Irish potato } \\
\text { Margarine } \\
\text { Radish } \\
\text { Boiled rice }\end{array}$ & $\begin{array}{r}100 \\
150 \\
100 \\
10 \\
10 \\
150 \\
30 \\
20 \\
320\end{array}$ & $\begin{array}{r}79 \\
117 \\
25 \\
40 \\
-117 \\
222 \\
3 \\
448\end{array}$ & $\begin{array}{r}17.0 \\
2.8 \\
1.4 \\
- \\
2.8 \\
= \\
6.7\end{array}$ \\
\hline Dinner & $\begin{array}{l}\text { Soup } \\
\text { Boiled fish } \\
\text { Vegetable } \\
\text { Pickle } \\
\text { Rice }\end{array}$ & $\begin{array}{l}\text { Tofu (Bean curd) } \\
\text { Miso (Bean paste) } \\
\text { Spanish macherel } \\
\text { Sugar } \\
\text { Soy sauce } \\
\text { Cabbage } \\
\text { Radish } \\
\text { Boiled rice }\end{array}$ & $\begin{array}{r}50 \\
20 \\
100 \\
5 \\
10 \\
100 \\
20 \\
320\end{array}$ & $\begin{array}{r}32 \\
31 \\
110 \\
20 \\
13 \\
3 \\
448\end{array}$ & $\begin{array}{r}3.0 \\
2.5 \\
20.0 \\
- \\
1 . \overline{4} \\
\overline{6.7}\end{array}$ \\
\hline Total & & & $\begin{array}{l}(1) \\
(2)\end{array}$ & $\begin{array}{l}1,905 \\
2,127\end{array}$ & $\begin{array}{l}72.3 \\
72.3\end{array}$ \\
\hline
\end{tabular}




\section{Metabolism Experiment.}

The carotene-deficient diet was given every day (the method of preparation differed every day though the ingredients were the same) and the total feces excreted the following day was collected. The feces was weighed, mixed well and a small aliquot was taken for determining the carotene content. Even with this carotene-deficient diet, the carotene content of the feces was never zero but measurable quantities were demonstrated. This diet was continued for several days. Food containing carotene was then given at lunch time and the carotene content of the feces excreted the following day measured. The carotene content of the feces of the basal diet was subtracted and the difference, which was the real quantity excreted, was subtracted from the quantity of carotene ingested and this value was assumed to be the quantity absorbed. The percentage absorption was calculated from the quantity absorbed and the quantity taken. The carotene excretion was measured every day until a constant value was obtained. Data in which the effect of food taken before was apparent, were omitted as were those obtained at times of diarrhea.

\section{Absorption of Pure Carotene Solution.}

Two mg $(\alpha, 80 \gamma, \beta, 1680 \gamma)$ crystalline carotene (prepared from benzenedissolved carotene by evaporation under reduced pressure) was dissolved in $2 \mathrm{ml}$ olive oil. This was absorbed on about $10 \mathrm{~g}$ of bread and given at lunch time.

\section{Carrot Diet.}

When cooked carrot was given, the carrot was sliced in about $5 \mathrm{~mm} \mathrm{sec-}$ tions and seasoned with soy sauce and sugar and when grated carrot was given, raw carrot was grated with a radish-grater.

\section{Pumpkin Diet.}

The pumpkin was boiled and strained. In the experiment, the rind was removed in some cases and included in the others.

\section{Dried Seaweed Diet.}

Ten g dried seaweed "Asakusanori" (produced at Omori), i.e., 31/2 sheets, was placed in an oven at $80^{\circ}$ for 3 minutes, cut into about $1 \mathrm{~cm}^{2}$ pieces, seasoned with a small quantity of salt and sodium glutamate, soaked in hot water and taken.

\section{Spinach Diet.}

The leafy part of the spinach was boiled and strained.

\section{Results}

\section{Absorption of Pure Carotene.}

Table II shows the results of the experiment with the oil solution of carotene. Absorption of $\beta$-carotene is high and without correction for the $\beta$ carotene in the basal diet, it is 84 per cent and with correction, it becomes 98 per cent. With a suspension of carotene, instead of the oil solution, absorption was poor. Whether this was due to the mode of administration is not clear but on the third day after cessation of administration of the suspension, a small quantity of carotene was found in the feces in a crystalline form. It is therefore suggested that carotene is poorly absorbed in a crystalline form. 
TABLE II

Absorption of Oily Solution of Pure Carotene.

I, Basal diet. II, I + Carotene in $2 \mathrm{ml}$ olive oil containing $1680 \gamma \beta$-carotene.

\begin{tabular}{|c|c|c|c|c|c|c|}
\hline Diet & & & Daily feces & $\beta$-Carotene ex & creted & Absorption \\
\hline \multirow{4}{*}{ I } & \multirow{4}{*}{ May } & & $g$ & \multicolumn{2}{|l|}{$\gamma$} & \multirow[t]{4}{*}{ per cent } \\
\hline & & 1 & 89 & 238 & & \\
\hline & & 12 & 100 & 252 & & \\
\hline & & & & $245^{b}$ & & \\
\hline \multirow{5}{*}{ II } & & 13 & 110 & 280 & $(35)^{a}$ & 98 \\
\hline & & 14 & 105 & 276 & (31) & 98 \\
\hline & & 15 & 90 & 287 & $(42)$ & 97.5 \\
\hline & & 16 & 98 & 258 & (13) & 99.3 \\
\hline & & & & $275^{b}$ & $(30)^{b}$ & $98^{b}$ \\
\hline
\end{tabular}

${ }^{a}$ The parenthesized figures indicate the corrected amount of excreted $\beta$-carotene.

$b$ Average. (Same in the following tables).

2. Carotene Absorption from Carrot Diet.

The results of the cooked carrot diet are shown in Table III and the

TABLE III

Carotene Absorption from Cooked Carrot.

I, Basal diet. II, I $+50 \mathrm{~g}$ cooked carrot containing $2652 \gamma \beta$-carotene.

Supplemented with $20 \mathrm{~g}$ fried bean curd.

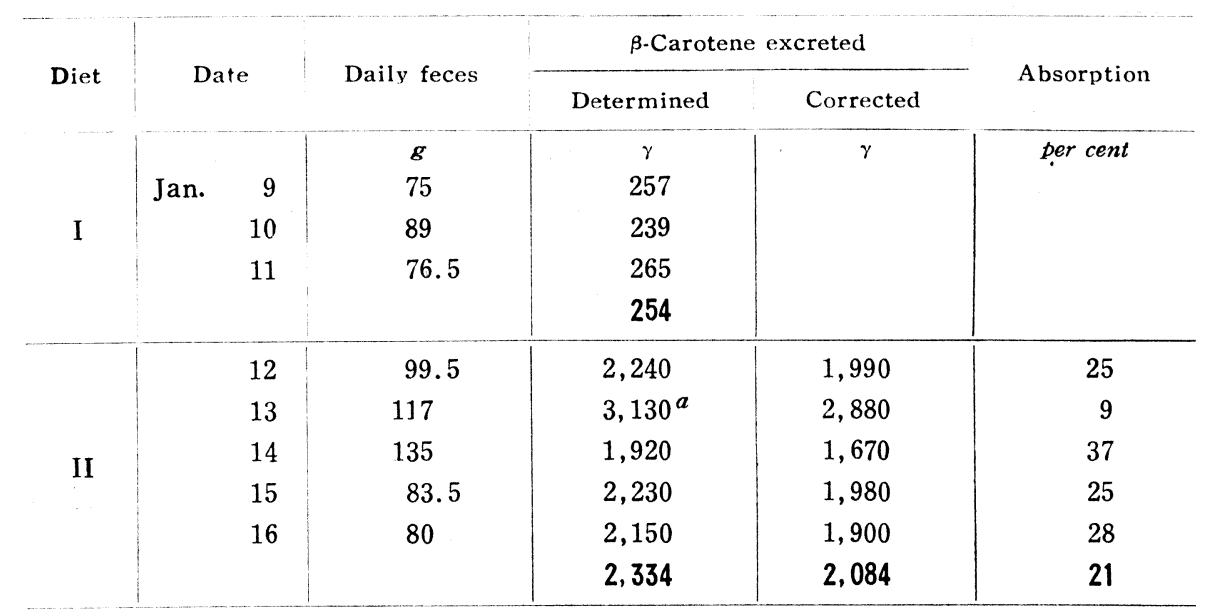

${ }^{a}$ Diarrhea

results with raw grated carrot are shown in Table IV. It can be seen in Table III that the excretion of $\beta$-carotene with the basal diet is $254 \gamma$ and when this is corrected, the percentage absorption of $\beta$-carotene is 21 . A 
comparison was made of the $\beta$-carotene content between raw and cooked $(1 \mathrm{~g}$ for 8 minutes) sliced carrot and only a loss of 3.5 per cent was found by the process of cooking.

Table $\mathrm{V}$ shows that the absorption of $\beta$-carotene from raw grated carrot was 21 per cent. The absorption from grated carrot cooked for 3 minutes was 48 and when this was supplemented with $10 \mathrm{~g}$ margraine, the absorption was 46 per cent. The $\beta$-carotene excreted $w$ ith the basal diet in this experiment was $247 \gamma$ and the percentage absorption were calculated from this. From the results, it can be seen that absorption is poor with raw grated carrot, that the absorption rises 2.4 times by cooking and there is a slight but not significant drop in absorption with addition of margarine.

\section{Carrot Absorption from Pumpkin Diet.}

Table $\mathrm{V}$ shows the results of the experiment with the pumpkin (strained including rind) and Table VI, the results obtained with the squash (strained, peeled). It can be seen in Table $\mathrm{V}$ that the absorption of $\beta$-carotene, after correction for the carotene of the basal diet, was 53 per cent. With addition of $30 \mathrm{~g}$ margarine, the adsorption was 69 and with addition of $30 \mathrm{~g}$ olive oil, it was 64 percent. In other words, the addition of margarine or oil increased the absorption of carotene but margarine had a slightly greater effect. In Table VI, the $\beta$-carotene excreted in the feces with the basal diet was $246 \gamma$ and when the values are corrected for this, the percentage absorption becomes 35 and with addition of $10 \mathrm{~g}$ margarine or $10 \mathrm{~g}$ olive oil, the absorption is 38 , and 39 per cent respectively. In this case, the addition of oil had little effect on the absorption.

\section{TABLE IV}

Carotene Absorption from Grated Carrot.

I, Basal diet. II, $50 \mathrm{~g}$ raw grated carrot $(\beta, 2100 \boldsymbol{\gamma})$, mixed with $100 \mathrm{~g}$ mashed potato. III, $50 \mathrm{~g}$ grated carrot, cooked 3 minites, mixed with $100 \mathrm{~g}$ mashed potato. IV, III + $10 \mathrm{~g}$ margarine.

\begin{tabular}{|c|c|c|c|c|c|}
\hline \multirow{2}{*}{ Diet } & \multirow{2}{*}{ Date } & \multirow{2}{*}{ Daily feces } & \multicolumn{2}{|c|}{$\beta$-Carotene excreted } & \multirow{2}{*}{ Absorption } \\
\hline & & & Determined & Corrected & \\
\hline I & $\begin{array}{ll}\text { June } & 10 \\
& 11\end{array}$ & $\begin{array}{c}g \\
85 \\
95\end{array}$ & $\begin{array}{c}\gamma \\
242 \\
252 \\
247\end{array}$ & $\gamma$ & per cent \\
\hline II & $\begin{array}{l}14 \\
15\end{array}$ & $\begin{array}{l}108 \\
104\end{array}$ & $\begin{array}{l}1,945 \\
1,890 \\
1,917\end{array}$ & $\begin{array}{l}1,698 \\
1,643 \\
1,670\end{array}$ & $\begin{array}{l}19 \\
22 \\
21\end{array}$ \\
\hline III & $\begin{array}{l}16 \\
17 \\
18\end{array}$ & $\begin{array}{l}86 \\
80.5 \\
81\end{array}$ & $\begin{array}{l}1,340 \\
1,375 \\
1,320 \\
1,345\end{array}$ & $\begin{array}{l}1,093 \\
1,128 \\
1,073 \\
1,098\end{array}$ & $\begin{array}{l}48 \\
46 \\
49 \\
48\end{array}$ \\
\hline IV & $\begin{array}{l}19 \\
20\end{array}$ & $\begin{array}{l}97 \\
88\end{array}$ & $\begin{array}{l}1,367 \\
1,425 \\
1,396\end{array}$ & $\begin{array}{l}1,120 \\
1,178 \\
1,149\end{array}$ & $\begin{array}{l}47 \\
44 \\
46\end{array}$ \\
\hline
\end{tabular}


TABLE V

Carotene Absorption from Pumpkin (strained).

I, Basal diet. II, $300 \mathrm{~g}$ pumpkin (strained, including rind) $(\beta, 873 \gamma)$.

III, II + $30 \mathrm{~g}$ margarine. IV, III $+30 \mathrm{~g}$ olive oil.

\begin{tabular}{|c|c|c|c|c|c|}
\hline \multirow{2}{*}{ Diet } & \multirow{2}{*}{ Date } & \multirow{2}{*}{ Daily feces } & \multicolumn{2}{|c|}{$\beta$-Carotene excreted } & \multirow{2}{*}{ Absorption } \\
\hline & & & Determined & Corrected & \\
\hline I & $\begin{array}{ll}\text { Feb. } & 17 \\
& 18 \\
& 19\end{array}$ & $\begin{array}{r}g \\
108 \\
65 \\
78\end{array}$ & $\begin{array}{l}\gamma \\
692^{a} \\
225 \\
265 \\
245\end{array}$ & $\gamma$ & per cent \\
\hline II & $\begin{array}{l}20 \\
21 \\
22\end{array}$ & $\begin{array}{l}82.5 \\
61 \\
99.5\end{array}$ & $\begin{array}{l}677 \\
615 \\
674 \\
655\end{array}$ & $\begin{array}{l}432 \\
370 \\
429 \\
410\end{array}$ & $\begin{array}{l}51 \\
58 \\
51 \\
53\end{array}$ \\
\hline III & $\begin{array}{l}23 \\
24 \\
25\end{array}$ & $\begin{array}{l}79.5 \\
95 \\
68\end{array}$ & $\begin{array}{l}565 \\
549 \\
435 \\
516\end{array}$ & $\begin{array}{l}320 \\
304 \\
190 \\
271\end{array}$ & $\begin{array}{l}63 \\
65 \\
78 \\
69\end{array}$ \\
\hline IV & $\begin{array}{l}26 \\
27 \\
28\end{array}$ & $\begin{array}{l}69 \\
66 \\
90\end{array}$ & $\begin{array}{l}568 \\
558 \\
549 \\
556\end{array}$ & $\begin{array}{l}323 \\
313 \\
304 \\
313\end{array}$ & $\begin{array}{l}63 \\
64 \\
65 \\
64\end{array}$ \\
\hline
\end{tabular}

${ }^{a}$ Carotene given up to February 14, switched to basal diet on $15 \mathrm{th}$, no bowel movement on 16 th.

TABLE VI

Carotene Absorption from Squash (strained).

I, Basal diet. II, I $+150 \mathrm{~g}$ squash (inner meat only, cooked, containing $3240 \boldsymbol{\gamma}$ $\beta$-carotene). III, II containing $3200 \boldsymbol{\gamma} \beta$-carotene $+10 \mathrm{~g}$ margarine.

IV, I containing $3170 \gamma \beta$-carotene $+10 \mathrm{~g}$ olive oil.

\begin{tabular}{|c|c|c|c|c|c|c|}
\hline \multirow{2}{*}{ Diet } & \multirow{2}{*}{\multicolumn{2}{|c|}{ Date }} & \multirow{2}{*}{ Daily feces } & \multicolumn{2}{|c|}{$\beta$-Carotene excreted } & \multirow{2}{*}{ Absorption } \\
\hline & & & & Determined & Corrected & \\
\hline I & July & $\begin{array}{l}3 \\
4\end{array}$ & $\begin{array}{c}g \\
90 \\
82\end{array}$ & $\begin{array}{c}\gamma \\
240 \\
252 \\
246\end{array}$ & $\gamma$ & per cent \\
\hline II & & $\begin{array}{l}5 \\
6\end{array}$ & $\begin{array}{l}85 \\
92\end{array}$ & $\begin{array}{l}2,350 \\
2,355 \\
2,353\end{array}$ & $\begin{array}{l}2,104 \\
2,109 \\
2,106\end{array}$ & $\begin{array}{l}35 \\
35 \\
35\end{array}$ \\
\hline III & & $\begin{array}{l}7 \\
8\end{array}$ & $\begin{array}{l}88 \\
95\end{array}$ & $\begin{array}{l}2,244 \\
2,220 \\
2,232\end{array}$ & $\begin{array}{l}1,998 \\
1,954 \\
1,976\end{array}$ & $\begin{array}{l}38 \\
39 \\
38\end{array}$ \\
\hline IV & & $\begin{array}{r}9 \\
10\end{array}$ & $\begin{array}{r}78 \\
100\end{array}$ & $\begin{array}{l}2,160 \\
2,230 \\
2,195\end{array}$ & $\begin{array}{l}1,914 \\
1,984 \\
1,949\end{array}$ & $\begin{array}{l}40 \\
37 \\
39\end{array}$ \\
\hline
\end{tabular}




\section{Carotene Absorption from Dried Seaweed Diet.}

As can be seen in Table VII, the daily ingestion of $10 \mathrm{~g}$ dried seaweed containing $2060 \gamma \beta$-carotene is somewhat excessive for the test subject. The

TABLE VII

Carotene Absorption from Dried Seaweed.

I, Basal diet. II, I $+10 \mathrm{~g}$ dried seaweed containing $2060 \boldsymbol{\gamma} \boldsymbol{\beta}$-carotene.

\begin{tabular}{|c|c|c|c|c|c|}
\hline \multirow{2}{*}{ Diet } & \multirow{2}{*}{ Date } & \multirow{2}{*}{ Daily feces } & \multicolumn{2}{|c|}{$\beta$-Carotene excreted } & \multirow{2}{*}{ Absorption } \\
\hline & & & Determined & Corrected & \\
\hline I & $\begin{array}{ll}\text { Feb. } & 5 \\
6\end{array}$ & \begin{tabular}{l}
\multicolumn{1}{c}{$\boldsymbol{g}$} \\
90.5 \\
61
\end{tabular} & $\begin{array}{c}\gamma \\
316 \\
237 \\
277\end{array}$ & $\gamma$ & per cent \\
\hline II & $\begin{array}{r}7 \\
8 \\
9 \\
10 \\
11\end{array}$ & $\begin{array}{c}82.2 \\
87.7 \\
102 \\
70 \\
90\end{array}$ & $\begin{array}{l}2,220 \\
2,102 \\
2,292 \\
1,930 \\
2,340 \\
2,177\end{array}$ & $\begin{array}{l}1,943 \\
1,825 \\
2,015 \\
1,653 \\
2,063 \\
1,900\end{array}$ & $\begin{array}{r}6 \\
11 \\
2 \\
20 \\
0 \\
8\end{array}$ \\
\hline
\end{tabular}

$\beta$-carotene content of the feces with the basal diet was $277 \gamma$ and when the value during administration of dried seaweed is corrected for this, the percentage absorption is 8 . There is a fluctuation from day to bay, but the percentage absorption is considered about 10 . The absorption of carotene in dried seaweed was thus found to be very poor.

This experiment was repeated on August 7 and $10 \mathrm{~g}$ dried seaweed containing $1710 \gamma \beta$-carotene was administered. Diarrhea, however, occurred from that day and the absorption of $\beta$-carotene was 4 per cent and the experiment was obliged to be discontinued.

5. Carotene Absorption from Shellfish (Tapes philippinarum) Diet.

It has been reported by Kawaguchi that vitamin A is scarcely found in Tapes phillippinarum and other shellfish and only carotene is found as a vitamin A source. This finding being different from that of other animals, an experiment was carried out concerning the absorbability of this carotene. The chromatographic findings and the ultraviolet absorption spectrum of the carotene fraction coincide well with those of $\beta$-carotene. In this experiment, $200 \mathrm{~g}$ of cooked shellfish was administered. This was quite a large quantity for the test subject to take at one time but the $\beta$-carotene contained in it was only $120 \%$. The feces become soft on the third day of the experiment and on the fourth day there was diarrhea with several bowel movements a day so the experiment was stopped. The $\beta$-carotene content of the feces with the basal diet was $252 \gamma$ and following administration of the shellfish the $\beta$-carotene content rose to $338 ;$ but with correction for the basal diet, the value became $136 r$ and the percentage absorption became negative. The quantity of carotene given in this experiment is however small and the value of the basal diet is large compared with the experimental value so this study is not 
considered accurate. It is suggested, however, that there is very little absorption of carotene.

TABLE VIII

Carotene Absorption from Tapes philippinarum.

I, Basal diet. II, I $+200 \mathrm{~g}$ shellfish, cooked 3 minutes, containing $120 \gamma$ $\beta$-carotene.

\begin{tabular}{|c|c|c|c|c|c|}
\hline \multirow{2}{*}{ Diet } & \multirow{2}{*}{ Date } & \multirow{2}{*}{ Daily feces } & \multicolumn{2}{|c|}{$\beta$. Carotene excreted } & \multirow{2}{*}{ Absorption } \\
\hline & & & Determined & Corrected & \\
\hline I & $\begin{array}{r}\text { March } 12 \\
13\end{array}$ & $\begin{array}{c}g \\
86 \\
73\end{array}$ & $\begin{array}{c}\gamma \\
241 \\
264 \\
252\end{array}$ & $\gamma$ & per cent \\
\hline II & $\begin{array}{l}14 \\
15 \\
16^{b}\end{array}$ & $\begin{array}{l}70 \\
140.5^{a} \\
108.5^{a}\end{array}$ & $\begin{array}{l}360 \\
392 \\
412 \\
388\end{array}$ & $\begin{array}{l}108 \\
140 \\
160 \\
136\end{array}$ & $\begin{array}{l}-3 \\
-3 \\
-15 \\
-0\end{array}$ \\
\hline
\end{tabular}

${ }^{a}$ Soft stool. ${ }^{b}$ Discontinued because of diarrhea on the 17 th.

TABLE IX

Carotene Absorption from Spinach (strained) and the Effect of Tocopherol.

I, Basal diet. II, I $+60 \mathrm{~g}$ spinach (leafy part strained) containing $2360 \boldsymbol{\gamma}$ $\boldsymbol{\beta}$-carotene. III, II containing $2538 \boldsymbol{\gamma} \boldsymbol{\beta}$-carotene $+6 \mathrm{~g}$ margarine. IV, II containing $2500 \boldsymbol{\gamma} \boldsymbol{\beta}$-carotene $+6 \mathrm{~g}$ margarine $+10 \mathrm{mg} \boldsymbol{\alpha}$-tocopherol.

$\mathrm{V}$, II containing $2380 \boldsymbol{\gamma} \boldsymbol{\beta}$-carotene $+6 \mathrm{~g}$ margarine $+100 \mathrm{mg} \boldsymbol{\alpha}$-tocopherol.

\begin{tabular}{|c|c|c|c|c|c|}
\hline \multirow{2}{*}{ Diet } & \multirow{2}{*}{ Date } & \multirow{2}{*}{ Daily feces } & \multicolumn{2}{|c|}{$\beta$-Carotene excreted } & \multirow{2}{*}{ Absorption } \\
\hline & & & Determined & Corrected & \\
\hline I & $\begin{array}{cr}\text { March } & 30 \\
& 31 \\
\text { April } & 1\end{array}$ & $\begin{array}{c}g \\
75 \\
80 \\
72\end{array}$ & $\begin{array}{c}\gamma \\
255 \\
252 \\
250 \\
253\end{array}$ & $\gamma$ & per cent \\
\hline II & $\begin{array}{l}2 \\
3 \\
4\end{array}$ & $\begin{array}{l}95 \\
78 \\
80\end{array}$ & $\begin{array}{l}1,866 \\
1,824 \\
1,815 \\
1,835\end{array}$ & $\begin{array}{l}1,613 \\
1,571 \\
1,562 \\
1,582\end{array}$ & $\begin{array}{l}33 \\
33 \\
34 \\
33\end{array}$ \\
\hline III & $\begin{array}{l}5 \\
6 \\
7\end{array}$ & $\begin{array}{l}82 \\
78 \\
75\end{array}$ & $\begin{array}{l}1,795 \\
1,883 \\
1,762 \\
1,813\end{array}$ & $\begin{array}{l}1,542 \\
1,630 \\
1,509 \\
1,560\end{array}$ & $\begin{array}{l}39 \\
36 \\
41 \\
39\end{array}$ \\
\hline IV & $\begin{array}{r}8 \\
9 \\
10\end{array}$ & $\begin{array}{l}81 \\
80 \\
73\end{array}$ & $\begin{array}{l}1,709 \\
1,733 \\
1,606 \\
1,683\end{array}$ & $\begin{array}{l}1,456 \\
1,480 \\
1,353 \\
1,430\end{array}$ & $\begin{array}{l}42 \\
41 \\
45 \\
43\end{array}$ \\
\hline $\mathrm{V}$ & $\begin{array}{l}11 \\
12 \\
13\end{array}$ & $\begin{array}{l}87 \\
83 \\
76\end{array}$ & $\begin{array}{l}1,565 \\
1,646 \\
1,611 \\
1,607\end{array}$ & $\begin{array}{l}1,312 \\
1,393 \\
1,358 \\
1,321\end{array}$ & $\begin{array}{l}45 \\
41 \\
43 \\
43\end{array}$ \\
\hline
\end{tabular}




\section{Carotene Absorption from Spinach Diet.}

The effects of fat, tocopherol and cyanocobalamin on the absorption of carotene when $60 \mathrm{~g}$ strained spinach containing $2340 \gamma \beta$-carotene is administered, are listed in Tables IX and $X$. As shown in Table IX, the daily

TABLE X

Carotene Absorption from Spinach (strained) and the Effect of Vitamin $B_{12}$.

I, Basal diet. II, I $+50 \mathrm{~g}$ spinach (leafy part, strained) containing $3430 \boldsymbol{\gamma} \boldsymbol{\beta}$ carotene. III, II containing $3430 \gamma \beta$-carotene $+5 \gamma$ B 12 . IV, II containing $3220 \boldsymbol{\gamma} \beta$-carotene $+5 \boldsymbol{\gamma} \mathrm{B}_{12}+6 \mathrm{~g}$ margarine.

\begin{tabular}{|c|c|c|c|c|c|}
\hline \multirow{2}{*}{ Diet } & \multirow{2}{*}{ Date } & \multirow{2}{*}{ Daily feces } & \multicolumn{2}{|c|}{$\beta$-Carotene excreted } & \multirow{2}{*}{ Absorption } \\
\hline & & & Determined & Corrected & \\
\hline I & $\begin{array}{ll}\text { April } & 17 \\
& 18 \\
& 19\end{array}$ & $\begin{array}{c}g \\
57.5 \\
142 \\
93\end{array}$ & $\begin{array}{c}\gamma \\
226 \\
197 \\
304 \\
262\end{array}$ & $\gamma$ & per cent \\
\hline II & $\begin{array}{l}20 \\
21 \\
22\end{array}$ & $\begin{array}{r}96 \\
100 \\
90\end{array}$ & $\begin{array}{l}2,610 \\
2,480 \\
2,530 \\
2,540\end{array}$ & $\begin{array}{l}2,348 \\
2,218 \\
2,268 \\
2,278\end{array}$ & $\begin{array}{l}33 \\
37 \\
36 \\
35\end{array}$ \\
\hline III & $\begin{array}{l}23 \\
24 \\
25\end{array}$ & $\begin{array}{l}93 \\
86 \\
97\end{array}$ & $\begin{array}{l}2,410 \\
2,500 \\
2,465 \\
2,456\end{array}$ & $\begin{array}{l}2,148 \\
2,238 \\
2,203 \\
2,194\end{array}$ & $\begin{array}{l}39 \\
37 \\
38 \\
38\end{array}$ \\
\hline IV & $\begin{array}{l}26 \\
27 \\
28^{a}\end{array}$ & $\begin{array}{r}93 \\
100 \\
140\end{array}$ & $\begin{array}{l}2,330 \\
2,520 \\
2,570 \\
2,473\end{array}$ & $\begin{array}{l}2,068 \\
2,258 \\
2,308 \\
2,211\end{array}$ & $\begin{array}{l}41 \\
36 \\
35 \\
37\end{array}$ \\
\hline
\end{tabular}

excretion of $\beta$-carotene with the basal diet was $253 \gamma$, the corrected value for absorption after administration of spinach was 33 per cent, the absorption with addition of $6 \mathrm{~g}$ margarine was 39 and the absorption with the additional supplementation of 10 and $100 \mathrm{mg} \alpha$-tocopherol was 43 and 43 per cent respectively, i.e., absorption rose with addition of margarine, rose somewhat higher with further addition of tocopherol though there was little difference whether 10 or $100 \mathrm{mg}$ tocopherol was added.

The $\beta$-carotene content of the spinach in this experiment was $41.2 \mathrm{r} / \mathrm{g}$. When cooked for 3 minutes, the value dropped 3.3 per cent to $39.8 \mathrm{r} / \mathrm{g}$ and with straining, there was a decrease of 5 per cent to $39.3 \mathrm{r} / \mathrm{g}$. It can be seen that the loss by cooking is small.

Table $\mathrm{X}$ shows the results when the spinach was supplemented with $5 r$ $\mathrm{B}_{12}$ and in the case when $6 \mathrm{~g}$ margarine was added in addition to $\mathrm{B}_{12}$. The $\beta$-carotene content of the feces with the basal diet was $262 \gamma$ and the corrected percentage absorption with the spinach diet was 35 . A corrected value of 38 and 37 per cent were obtained with $\mathrm{B}_{12}$ supplementation and $\mathrm{B}_{12}$ plus 
margarine supplementation respectively and it can be seen that those had almost no effect.

\section{DISCUSSION}

\section{Absorption of Carotene in Food.}

The above findings are summarized in Table XI. It can be seen that

TABLE XI

Summary of Carotene Absorption.

Mag, Margarine ; Toc, Tocopherol ; Olo, Olive oil.

\begin{tabular}{|c|c|c|c|c|}
\hline Source & $\begin{array}{l}\beta \text {-Carotene } \\
\text { content }\end{array}$ & $\mathrm{Su}_{1}$ & ment & $\begin{array}{l}\text { Carotene } \\
\text { absorption }\end{array}$ \\
\hline $\begin{array}{l}\text { Pure carotene crystal (suspension) } \\
\text { " } \\
\text { Pure carotene oil solution }\end{array}$ & $\begin{array}{l}1,620 \\
1,620 \\
1,680\end{array}$ & $\begin{array}{l}\text { Mag } \\
\text { Olo }\end{array}$ & $\begin{array}{l}0 \\
30 \mathrm{~g} \\
2 \mathrm{~g}\end{array}$ & $\begin{array}{l}58 \\
47 \\
98\end{array}$ \\
\hline $\begin{array}{ccc}\text { Cooked spinach } & \\
\text { Grated } & , & \\
, " & , & \text { (raw) } \\
, " & , & ,,\end{array}$ & $\begin{array}{l}2,652 \\
2,100 \\
2,100 \\
2,100\end{array}$ & Mag & $\begin{array}{l}0 \\
0 \\
0 \\
10 \mathrm{~g}\end{array}$ & $\begin{array}{l}21 \\
21 \\
48 \\
46\end{array}$ \\
\hline $\begin{array}{c}\text { Pumpkin (strained) } \\
\text { Squash }(\text { strained) }\end{array}$ & $\begin{array}{r}873 \\
873 \\
873 \\
3,240 \\
3,200 \\
3,170\end{array}$ & $\begin{array}{l}\text { Mag } \\
\text { Olo } \\
\text { Mag } \\
\text { Olo }\end{array}$ & $\begin{array}{c}0 \\
30 \mathrm{~g} \\
30 \mathrm{~g} \\
0 \\
10 \mathrm{~g} \\
10 \mathrm{~g}\end{array}$ & $\begin{array}{l}53 \\
69 \\
64 \\
35 \\
38 \\
39\end{array}$ \\
\hline $\begin{aligned} \text { Spinach } & (\text { strained) } \\
, & , \\
, & \\
, & , \\
, & \end{aligned}$ & $\begin{array}{l}2,360 \\
2,538 \\
2,500 \\
2,380 \\
3,430 \\
3,430 \\
3,220\end{array}$ & $\begin{array}{l}\text { Mag } \\
\left\{\begin{array}{l}\text { Mag } \\
\text { Toc }\end{array}\right. \\
\left\{\begin{array}{l}\text { Mag } \\
\text { Toc }\end{array}\right. \\
\begin{array}{l}\mathrm{B}_{12} \\
\mathrm{~B}_{12} \\
\mathrm{Mag}\end{array}\end{array}$ & $\begin{array}{c}0 \\
6 \mathrm{~g} \\
6 \mathrm{~g} \\
10 \mathrm{mg} \\
6 \mathrm{~g} \\
100 \mathrm{mg} \\
0 \\
5 \mathrm{r} \\
5 \mathrm{r} \\
6 \mathrm{~g}\end{array}$ & $\begin{array}{l}33 \\
39 \\
43 \\
\\
43 \\
35 \\
38 \\
37\end{array}$ \\
\hline Dried seaweed & 2,060 & & 0 & 8 \\
\hline Shellfish (Tapes philippinarum) & 120 & & 0 & 0 \\
\hline
\end{tabular}

the percentage absorption of $\beta$-carotene with ordinary diet is $20-40$ and when the food is strained, so that it is more readily absorbed and with the addition of oil or tocopherol, the absorption rise to 60 per cent or more. The absorption with dried seaweed was less than 10 per cent and with shellfish almost zero. It is true that in the case of the latter two, the quantity was much greater than that usually taken and resulted in softening of the feces and diarrhea and the absorption may have dropped below normal due to this but it can be said that absorption is poor.

If these values can be applied to the Japanese is general, the normal per- 
centage absorption of $\beta$-carotene in food would be about 30 and it would therefore be necessary to take 3 times the anticipated amount for proper nutrition.

\section{Carotene Requirements.}

In Sheffield, Hume et al. (1) have studied the vitamin A requirement in young adults using carotene alone as the source of vitamin A. They fed the test subjects a carotene-deficient diet and conducted preventive and therapeutic experiments. It was assumed that the minimal daily requirement was $1500 \mathrm{I}$. U., provided that all of the $\beta$-carotene was absorbed and in consideration of individual differences and margin of safety, it was stated that the requirement would be 2 times the above value, i.e., 3000 I. U. It was found on the basis of the carotene content of the feces that the percentage absorption of carotene is not 100 and in view of this, it was concluded that the daily requirement would be $4000 \mathrm{r}$. $\mathrm{u}$. in the case of pure carotene, 5000 in the case of homogenized carrot, 7500 in the case of cabbage or spinach and 12,000 I. U. in the case of cooked diced carrot. Calculation of the percentage absorption from these values gives 75, 60, 40 and 25 respectively and these figures are quite close to the results obtained by the authors.

\section{Absorbability of Carotene in Man Reported in the Literature.}

The values given in the literature vary as do the methods of determination, $(3,58,10-13,17,2124,27,32,33)$. Of these, the method of determination is not presented in some $(1,8)$ and coloring substances other than carotene may have been measured in some studies using chromatography $(1,3,7,9)$. Kreula (2) has used alumina chromatography but has developed with petroleum ether alone so it is considered that it is a weakly activated alumina and as $\alpha$-and $\beta$-carotenes are not separated with this adsorbent, it is assumed that he did not fractionate the carotene components. Hara and Nakano (21) have used alumina but have not separated carotene fractions. It has been reported that alumina causes isomerism of carotenoids and in the case of feces, where many types of pigment are present, $\mathrm{Ca}(\mathrm{OH})_{2}$ is more suited for separating the fractions of carotene than alumina. James et al. (10) have conducted a detailed study with $\mathrm{Ca}(\mathrm{OH})_{2}$ chromatography but used 25 per cent benzene-petroleum ether for developing, so the isolation of each carotene fraction is believed inadequate. The isolation of non-carotene pigments, therefore, is also considered inadequate. From these facts, it is suggested that the results of carotene absorption experiments presented in the literature require reinvestigation.

\section{Discussion on Carotene Absorption}

In this study, the quantity of carotene excreted in the feces subtracted from the quantity ingested was presumed to be the quantity absorbed and the ratio of the quantity absorbed to the quantity ingested to be the absorbability, whereby the decomposition of carotene in the digestive tract was not taken into consideration. If carotene is decomposed in the digestive tract, the absorbability would be still smaller. Kreula $(5,6)$ has reported that there is no loss in carotene by incubating at $37^{\circ}$ for 24 hours or storing for 8 days at $20^{\circ}$, but Ishii et al. (20) state that in experiments using artificial gastric juice, 24 per cent of the carotene contained in spinach, 18 per cent contained in 
the carrot and 27 per cent contained in dried seaweed is decomposed. In the study by the authors, the percentage absorption was: spinach, 33-43; carrot, 2148 and dried seaweed, 8. The decomposition in the case of dried seaweed, is therefore greater than the absorbability and the greater part of the absorption in the case of spinach and carrot would be due to decomposition. It is therefore assumed that Ishii's value are much higher than actually occur in nature. Be that as it may, there is no accurate method for determining the carotene broken down in the intestines so this factor was disregarded in this study.

\section{Excretion of Carotene with Carotene-Deficient Diet.}

Carotene is often observed in the feces of mice raised on a carotenedeficient diet by Kemmerer et al. (11), Ramasarma (12), and Russel et al. (13). The daily excretion in the feces is about $0.5-2 \gamma$. The absorption spectrum of this substance is clearly different from that of carotene, indicating it to be a non-carotene pigment. This shows the non-specificity of the quantitative method of carotene determination. James et al. (10) studied the excretion of carotene in 8 adults given a carotene-deficient diet and found the excretion of $83-315 r$. He however has failed to state whether the absorption spectrum was examined and it is not clear whether the substance studied is identical with carotene. The authors have found that there is excretion of $250 \mathrm{r}$ carotene a day with a carotene-free diet and the absorption spectrum of the carotene fraction showed absorption maxima at 450 and $475 \mathrm{~m} \mu$, closely resembling $\beta$-carotene in pattern. The chromatographic findings also coincided so that the major part is assumed to be $\beta$-carotene. The object of this study being to examine the absorbability of carotene in food, it is more convenient to omit the influence of non-food carotene and the quantitative determination of carotene is easier and more accurate by so doing. The correction for the carotene excreted with the basal diet was therefore made. The question of whether the small quantity of carotene contained in the basal diet is absorbed equally well as in the case of the basal diet plus carotene-rich fooodstuff, was considered but as can be seen in Table VIII, the carotene excreted in the feces would be greater than the quantity taken, if correction for the carotene in the basal diet is not made, so it is believed that this correction is rational.

\section{The Effect of Fat, Tocopherol and $B_{12}$ on Carotene Absorption.}

It has been shown that the absorption of carotene is promoted by the presence of fat in animals $(5,14)$ and man $(3,4,15)$. It has also been found that $\alpha$-tocopherol plays an important role in the utilization of carotene in the body, especially in growth $(16-18)$ and in the formation of vitamin $A$ in the liver (15). It has also been reported that the injection of vitamin $B_{12}$ in mice accelerates the utilization of carotene with promotion of growth and increase in deposition in the liver (19).

Under the conditions of this experiment, the addition of fat, tocopherol or vitamin $B_{12}$ had some accelerating effect on the absorption of carotene but the effect was not great. 


\section{SUMMARY}

The absorbability of $\beta$-carotene was studied in an adult, Japanese female under various conditions and with various kinds of food. The following values, in per cent, were obtained: pure carotene suspension, ca. 60; oil solution of pure carotene, 98 ; carrots cooked in the ordinary manner, 21 ; pumpkin, 35-53; and spinach, 33-35.

There is some increase in the absorbability with the addition of margarine or olive oil but under the conditions of the experiments, the increase was insignificant.

Supplementation of vitamin $\mathrm{B}_{12}$ or tocopherol resulted in some increase but the difference was not marked. The absorption with dried seaweed was 8 per cent and in the case of shellfish (Tapes philippinarum) there was scarcely any absorption. It is suggested that the seaweed and shellfish are poor sources of carotene.

\section{REFERENCES}

1. Hume, E. M, and Krebs, H. A., Med. Research Council Brit. Spec. Rept. Ser. 264 (1949).

2. Kreula, M., Ann. Acad. Sci. Fennicae. Ser. A. II. 38, 7 (1950) ; C. A. 45, $5251(1951)$.

3. Wilson, H. E. C., Ahmad, B., and Majumdar, B. N., Indian J. Med. Res. 24, 399 (1936).

4, v. Eekelen, M., and Pannevis, W., Nature 141, 203 (1938).

5. Kreula, M., and Virtanen, A. I., Upsala Läkarefören. Forh. 45, 355 (1939) ; C. A. 34, 5897 (1940).

6. Virtanen, A., and Kreula, M., Z. Physiol. Chem. 270, 141 (1941).

7. Eriksen, B., and Holygaard, A., Klin. Wschr. 20, 200 (1941).

8. Vitamin A-Subcommittee of the Accessory Food Factors Committee, Lister Inst. and Med. Res. Coun. Nature 156, 11 (1945).

9. v. Zeben, W., Z. Vitaminforsch. 17, 74 (1946).

10. James, W. H., and ElGindi, I. M., J. Nutrition 51, 97 (1953).

11. Kemmerer, A. R., and Fraps, A. R., ibid. 16, 309 (1938).

12. Ramasarma, G. B., and Hakin, D. N., Nature 145, 611 (1942).

13. Russel, W. C., Taylor, M. W., Walker, H. A., and Polskin, L. J., J. Nutrition 24, 199 (1942).

14. Ahmad, B., Biochem. J. 25, 1195 (1931).

15. Guggenheim, K., ibid. 38, 260 (1944).

16. Hickmann, K. C. D., Kaley, M. W., and Harris, P. L., J. Biol. Chem. 152. 303 (1944).

17. Hoehn, C. J., Arch. Biochem. 17, 337 (1948).

18. Burns, M. J., Hauge, S. N., and Quackenbush, F. W., Arch. Biochem. 30, 341, 347 (1951).

19. High, E. G., and Wilson. C. S. J. Nutrition 50, 203 (1952).

20. Ishii, R., and Iwagaki, C., Vitamins 9, 213 (1955).

21. Hara, M., and Nakano, N., Studies on Fat-Soluble Vitamins by Omori (Japanese). Daiichi-Shuppan K. K., Tokyo (1953). 